http://dx.doi.org/10.12775/szhf.2020.007

\author{
Anna Tomaszewska \\ UNIWERSYTET JAGIELLOŃSKI \\ E-MAIL: A.TOMASZEWSKA@IPHILS.UJ.EDU.PL \\ ORCID: 0000-0002-1002-3594
}

\title{
Filozofia religii Kanta w kontekście nowożytnego racjonalizmu religijnego*
}

\section{Wstęp: religia „w obrębie samego rozumu”}

Filozofia religii Immanuela Kanta stanowi przedmiot dyskusji i interpretacji, które od początku charakteryzowały się znacznym stopniem rozbieżności. Sam tytuł głównego dzieła o religii autorstwa filozofa z Królewca kryje pewną dwuznaczność: Religion innerhalb der Grenzen der bloßen Vernunft może bowiem sygnalizować zamiar zarówno wyznaczenia religii akceptowalnych przez rozum granic, jak i rozważania jej w odniesieniu do rozumu pozbawionego treści pochodzących z innych źródeł - tak rozpatrywana religia

* Artykuł powstał w ramach projektu badawczego Między sekularyzacja a reforma. Racjonalizm religijny końca XVII wieku i epoki Oświecenia (nr UMO-2018/31/B/HS1/02050), realizowanego w Instytucie Filozofii Uniwersytetu Jagiellońskiego w latach 2019-2022. Wcześniejsza wersja tego tekstu została zaprezentowana jako referat na konferencji Filozofia XVII wieku - jej źródła i kontynuacje, która odbyła się 25-26 czerwca 2018 roku na Uniwersytecie Mikołaja Kopernika w Toruniu. 
byłaby „ogołocona” z wszelkich elementów niewywodzących się z rozumu ${ }^{1}$. Oczywiście, Kantowska filozofia religii zakłada przeprowadzoną we wcześniejszych pismach krytykę ludzkich władz poznawczych; chodzi więc o rozum właściwy skończonym podmiotom poznającym, a nie o rozum w ogóle.

Zawarta w tytule Religii w obrębie samego rozumu dwuznaczność motywuje dwa rodzaje interpretacji. Z jednej strony daje podstawę do stwierdzenia, że filozof dokonuje racjonalizacji religii, redukując ją do treści mających rozumowe źródło i uzasadnienie. $Z$ drugiej strony zaś pozwala przypisać Kantowi intencje apologetyczne, sprowadzające się do racjonalnego uzasadnienia religii jako takiej, wykazania, że religię można rozpatrywać także z racjonalnego punktu widzenia, a nie jako przeciwieństwo racjonalności. Zwolennikiem tego drugiego ujęcia jest na przykład Stephen Palmquist, określający filozofię religii Kanta mianem "krytycznego mistycyzmu”2, czy Wilhelm Dilthey, zdaniem którego „nikt w Niemczech nie zdziałał tak wiele na rzecz propagowania autentycznej religijności (einer ernsten Religiosität)", jak Kant ${ }^{3}$. Z kolei australijski historyk idei Ian Hunter uważa królewieckiego filozofa za przedstawiciela "północnoniemieckiego racjonalizmu religijnego", opisując punkt widzenia osiemnastowiecznych pruskich władz odpowiedzialnych za politykę wyznaniową państwa ${ }^{4}$.

Rozbieżności interpretacyjne mogą wynikać z różnicy co do założeń metodologicznych samych komentatorów: traktując filozofię Kanta jako szczególny przypadek racjonalizmu religijnego, należy wziąć pod uwagę kontekst historyczny, w którym myśl Kantowska kształtowała się; szukając zaś w pismach królewieckiego filozofa argumentów za racjonalnością religii w ogóle, można abstrahować od zróżnicowanego historycznego tła owej myśli. To „ahistoryczne” podejście może być uzasadnione specyfiką samego stanowiska Kanta: filozofia transcendentalna, która w ostatnim niedokończonym

1 W sprawie znaczenia tytułowego „bloß” zob. Stephen Palmquist, „Does Kant Reduce Religion to Morality?", Kant-Studien 83/2 (1992): 129-148.

2 Tenże, Comprehensive Commentary on Kant's Religion within the Bounds of Bare Reason (Oxford and Chichester: Wiley Blackwell, 2015).

3 Wilhelm Dilthey, „Der Streit Kants mit der Zensur über das Recht freier Religionsforschung", w: Die Jugendgeschichte Hegels und andere Abhandlungen zur Geschichte des deutschen Idealismus (Göttingen: Vandenhoeck und Ruprecht, 1990), 285-309.

4 Ian Hunter, „Kant's Religion and Prussian Religious Policy”, Modern Intellectual History 2/1 (2005): 1-27. 
dziele - Opus postumum - zostaje zdefiniowana jako „nauka o wiedzy czystej syntetycznej a priori na podstawie pojęć”, nie zajmuje się „czymś, co jak się zakłada, istnieje, lecz jedynie ludzkim duchem, który [jest] jej własnym my-

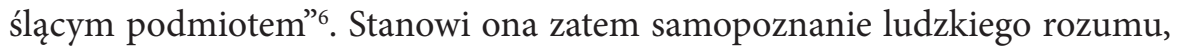
który w ujęciu Kanta jest aczasowy.

W niniejszym artykule zamierzam przyjrzeć się przede wszystkim dwóm wątkom Kantowskiej koncepcji religii: filozoficznej interpretacji Pisma św. oraz „deifikacji” rozumu praktycznego jako moralnego prawodawcy, uwzględniając przy tym do pewnego stopnia kontekst historyczny, w jakim koncepcja ta się kształtowała. W szczególności interesować mnie będzie powinowactwo idei Kantowskich z tymi, jakie można znaleźć wśród autorów, na których znaczny wpływ wywarła myśl Barucha Spinozy, w ostatnich dwóch dziesięcioleciach uznawana za główne źródło formacji ideowej zwanej radykalnym Oświeceniem ${ }^{7}$. Wskazując na to powinowactwo, można - jak sądzę - lepiej zrozumieć radykalizację filozofii religii Kanta pod koniec życia autora trzech Krytyk, na którą zwracają uwagę niektórzy współcześni bada$\mathrm{cze}^{8}$. Co więcej, dzięki temu można zobaczyć, że wbrew dość ugruntowanej opinii ${ }^{9}$ poglądy Kanta sytuują się bliżej nowożytnych i oświeceniowych heterodoksji niż apologetyki chrześcijaństwa.

5 OP, AA 21:52. Wszystkie fragmenty Opus postumum cytuję w tłumaczeniu własnym $\mathrm{w}$ oparciu o tekst oryginalny, podając odpowiednie sigla i numery stron według wydania Berlińskiej Akademii. Immanuel Kant, Gesammelte Schriften, hrsg.: Bd. 1-22 Preussische Akademie der Wissenschaften, Bd. 23 Deutsche Akademie der Wissenschaften zu Berlin, ab Bd. 2 Akademie der Wissenschaften zu Göttingen (Berlin, 1900ff).

6 OP, AA 21:78.

7 Zob. Jonathan Israel, Radical Enlightenment. Philosophy and the Making of Modernity 1650-1750 (Oxford: Oxford University Press, 2001).

8 Zob. na przykład Adela Cortina, „Die Auflösung des religiösen Gottesbegriffs im Opus postumum Kants", Kant-Studien 75/3 (1984): 280-293; Christopher Insole, The Intolerable God: Kant's Theological Journey (Grand Rapids MI: Eerdmans, 2016), rozdz. 8; Tomasz Kupś, Opus postumum Immanuela Kanta (Toruń: Wydawnictwo Naukowe Uniwersytetu Mikołaja Kopernika, 2016), rozdz. 5.

9 Zob. na przykład Friedrich Paulsen, Kant, der Philosoph des Protestantismus (Berlin: Reuther und Reichard, 1899); Norbert Fischer (hrsg.), Kant und der Katholizismus. Stationen einer wechselhaften Geschichte (Freiburg im Breisgau: Herder, 2005). 


\section{Racjonalizm religijny}

Przez racjonalizm religijny rozumiem pogląd, zgodnie z którym między wiarą a rozumem nie zachodzi relacja wykluczania się, lecz raczej zakresy tych dziedzin w znacznym stopniu pokrywają się. Pogląd ten pociąga za sobą określone podejście do interpretacji tekstów uznawanych w danej tradycji za objawione. Jak pisze Leszek Kołakowski, racjonalizm religijny „na gruncie kultury chrześcijańskiej” można rozumieć jako „zasadę, która poleca tak interpretować pisma kanoniczne, aby dopasować ich treść do wymogów «naturalnego» rozumu" ${ }^{10}$. Takie dopasowanie może wiązać się z rewizją, a w jej wyniku $-\mathrm{z}$ odrzuceniem pewnych treści owych pism jako zawierających sprzeczności lub niedających się uzgodnić z rozumem, ale może także polegać na przypisaniu tym treściom nowych znaczeń - na ich reinterpretacji. $\mathrm{W}$ pierwszym przypadku ${ }^{11}$ mielibyśmy do czynienia z poglądem zbliżonym do deizmu, rozumianym jako „wiara w Boga jako stwórcę nieba i ziemi” przy jednoczesnym odrzuceniu „wszystkich innych artykułów wiary religijnej”, w szczególności „Jezusa Chrystusa i jego doktryn”"

Opowiadając się za "teizmem moralnym” - negującym spekulatywne argumenty za istnieniem Boga i opierającym przekonanie o jego istnieniu na "podstawach praktycznych”13 - Kant stara się odciąć od deizmu. W Rozprawie filozoficznej o religii i moralności czytamy: „Wszelka religia stawia na czele moralność. [...] To więc jest pierwszy początek religii, która i bez teologii jest możliwa. Jest to naturalny postęp z moralności do religii. Religia nie potrzebuje spekulacyjnego poznania Boga" ${ }^{14}$. O ile więc deista może uznać

${ }^{10}$ Leszek Kołakowski, Świadomość religijna i więź kościelna (Warszawa: WN PWN, 2009), 150.

${ }^{11}$ Drugim zajmę się szerzej w trzeciej części artykułu.

12 Allen Wood, „Kant's Deism”, w: Kant's Philosophy of Religion Reconsidered, red. Philip J. Rossi, Michael J. Wreen (Bloomington: Indiana University Press, 1991), 2. Wood przytacza definicje deizmu sformułowane przez siedemnasto- i osiemnastowiecznych autorów: Pierre’a Vireta, Edwarda Stillingfleeta, Johna Drydena i Samuela Johnsona.

13 V-Phil-Th/Pölitz, AA 28:1011 (tłum. - A.T.).

14 Immanuel Kant, Rozprawa filozoficzna o religii i moralności/Philosophische Abhandlung über Religion und Moral, przeł. Krzysztof Celestyn Mrongowiusz (Toruń: Wydawnictwo Uniwersytetu Mikołaja Kopernika, 2006), 144. 
dane przekonanie teistyczne na podstawie racji rozumowych, takich jak argumenty dogmatycznej metafizyki, o tyle etyczny teista wyraźnie odrzuca niektóre - mianowicie spekulatywne - argumenty, próbując uprawomocnić takie przekonania. Różnica między Kantem a deistami sprowadza się jednak do rodzaju argumentów, jakie uznają za stosowne w uzasadnianiu religijnych przekonań; stąd też według niektórych komentatorów, na przykład Allena Wooda, Kant reprezentuje pewną odmianę deizmu ${ }^{15}$.

W Religii w obrębie samego rozumu Kant definiuje religię jako „poznanie wszystkich naszych obowiązków jako przykazań Bożych"16. Definicja ta zgodna jest ze stanowiskiem określonym przez filozofa mianem teizmu moralnego, w szczególności jeśli „obowiązki” rozumieć jako (przede wszystkim) obowiązki moralne. Jednak nawet jeśli znaczenie słowa „obowiązek” jest tu nieco szersze i obejmuje na przykład obowiązki związane ze sprawowaniem kultu, które nie mają moralnego znaczenia, Kantowska definicja umieszcza religię w kontekście praktycznym. W ujęciu, jakie proponuje autor trzech Krytyk, racjonalizm w kwestii wiary będzie zatem jednym ze stanowisk w ramach teizmu moralnego - takim, zgodnie z którym uznaje się ,jedynie naturalną religię za moralnie konieczną, tj. za obowiązek”, przy czym przez religię naturalną należy rozumieć taką religię, „w której muszę najpierw wiedzieć, iż coś jest obowiązkiem, zanim mogę uznać to za przykazanie Boże"17. Z kolei „czysty racjonalizm” według Kanta to takie stanowisko, które wprawdzie nie zaprzecza możliwości objawienia, ale też nie uznaje go za niezbędny element religii ${ }^{18}$. Chcąc więc przypisać Kantowi racjonalizm religijny, musimy pamiętać o jego agnostycyzmie w sprawie wartości poznawczej objawienia, czyli przede wszystkim chrześcijańskiego Pisma św. Agnostycyzm ten nie wyklucza możliwości „dopasowania” treści Pisma do „wymogów «naturalnego» rozumu”, o których pisał Kołakowski, jeżeli przez dopasowanie będziemy rozumieć przypisanie owym treściom nowych znaczeń - w wypadku Kanta będą to znaczenia etyczne.

15 Wood, „Kant's Deism”.

${ }^{16}$ Immanuel Kant, Religia w obrębie samego rozumu, przeł. A. Bobko (Kraków: Wydawnictwo Homini, 2007), 201.

17 Tamże, 202.

18 Tamże, 202-203. 
Powyżej scharakteryzowałam racjonalizm religijny jako pogląd głoszący, że zakresy dziedziny, do której należy wiara, oraz dziedziny zawierającej to, co racjonalne, pokrywają się. Pogląd ten jednak - jeśli chcielibyśmy przypisać go Kantowi - nie musi być równoznaczny z nadaniem przekonaniom religijnym statusu analogicznego do tego, jaki przysługuje przekonaniom konstytuującym wiedzę. Tak więc wiara może być racjonalna, różniąc się jednocześnie w swej istocie od wiedzy. Różnicę tę charakteryzuje Kant w Metodologii transcendentalnej - części Krytyki czystego rozumu - w następujący sposób. Dany podmiot ma wiedzę, gdy dysponuje uzasadnieniem „zarówno podmiotowo, jak i przedmiotowo wystarczającym" do tego, by jego przekonanie uznać za prawdziwe (Fürwahrhalten); gdy uzasadnienie przekonania jest ważne jedynie podmiotowo, wówczas uznanie tego przekonania za prawdziwe stanowi akt wiary ${ }^{19}$. Tym, co odróżnia uzasadnienie ważne podmiotowo od uzasadnienia ważnego przedmiotowo, jest zaś przede wszystkim to, że to pierwsze odnosi się do pewnych własności podmiotu czy też władz jego umysłu, a nie do własności pozaumysłowej rzeczywistości.

Podmiotowo ważne uzasadnienie przekonania religijnego, jak czytamy w eseju Co oznacza: orientować się w myśleniu?, odwołuje się do pojęcia „koniecznej potrzeby [Bedürfnis] rozumu"20. Określenie to sugeruje, jakoby uzasadnianie przekonań należących do „wiary rozumowej” sprowadzało się do wskazania na pewne uczucie czy poczucie właściwe rozumowi, analogiczne do intuicyjnego poczucia różnicy między prawą a lewą stroną naszego ciała, o którym pisze Kant nieco wcześniej we wspomnianym tekście. To właściwe rozumowi poczucie nie jest jednak nieokreśloną intuicją, lecz raczej wydaje się stanowić konsekwencję pewnego rozumowania, które można przedstawić w następujący sposób. Analizując pojęcie prawa moralnego, dochodzimy do pojęcia najwyższego dobra ${ }^{21}$ : moralności (cnoty etycznej) powiązanej

19 Immanuel Kant, Krytyka czystego rozumu, przeł. Roman Ingarden (Kęty: Wydawnictwo Antyk, 2001), 603 (KrV, A 822/B 850).

${ }^{20}$ Immanuel Kant, „Co oznacza: orientować się w myśleniu?”, w: O odkryciu, po którym wszelka nowa krytyka czystego rozumu jest zbędna ze względu na istnienie wcześniejszej i inne rozprawy filozoficzne, przeł. Translatorium Filozofii Niemieckiej Instytutu Filozofii UMK (Toruń: Wydawnictwo Naukowe Uniwersytetu Mikołaja Kopernika, 2009), 119.

${ }^{21},[\ldots]$ czyste, praktyczne zastosowanie rozumu polega na wyznaczaniu praw moralnych. One zaś wszystkie prowadzą do idei najwyższego dobra [...]”. Tamże, 117. 
z odpowiednio do niej proporcjonalną szczęśliwością. Moralność zakłada wolność, jej realizacja jest więc zależna od nas samych jako istot rozumnych i zdolnych do autodeterminacji własnej woli, szczęśliwość jednak zależy „również od natury”22, czyli od dziedziny zdeterminowanej przez prawa, których obowiązywanie wyklucza wolność. Aby najwyższe dobro mogło zostać urzeczywistnione, musi istnieć istota zdolna powiązać ze sobą dziedzinę moralności z dziedziną natury. Tą istotą miałby być Bóg. Istnienie Boga jako postulat rozumu praktycznego stanowi więc odpowiedź na racjonalną potrzebę dopasowania naszych pojęć moralnych do empirycznej rzeczywistości. Wiara moralna stanowiłaby tutaj rezultat racjonalnego pragnienia realizacji moralnego ideału w świecie czy też byłaby wyrazem nadziei na jego realizację ${ }^{23}$.

Czy przedstawiony wyżej argument Kanta powinien prowadzić do wniosku, że wiara jest konsekwencją uznania przez rozum własnych ograniczeń? Jeśli by tak było, nie moglibyśmy uważać Kanta za przedstawiciela racjonalizmu religijnego, religię bowiem należałoby wówczas przeciwstawić racjonalności i potraktować jako sferę stanowiącą swego rodzaju dopełnienie rozumu. Taka interpretacja Kantowskiego postulatu może być jednak trudna do uzgodnienia z tymi fragmentami pism filozofa, w których wyraźnie wskazuje on na rozum jako źródło przekonań religijnych. I tak, w Vorlesungen über die philosophische Religionslehre czytamy:

Wewnętrzne objawienie (innere Offenbarung) boskie jest objawieniem nam Boga przez nasz własny rozum; to ostatnie musi poprzedzać każde inne objawienie i służyć ocenie (zur Beurteilung) objawienia zewnętrznego. Musi stanowić kamień probierczy, za pomocą którego rozpoznaję, czy dane objawienie zewnętrzne jest naprawdę objawieniem Boga i czy dostarcza mi pojęć, które są w odniesieniu do Boga odpowiednie ${ }^{24}$.

22 Tamże.

${ }^{23} \mathrm{Za}$ interpretacją Kantowskiej wiary moralnej w kategoriach nadziei na urzeczywistnienie dobra najwyższego opowiada się Onora O’Neill w eseju „Kant on Reason and Religion”, The Tanner Lectures on Human Values, red. Grethe B. Peterson (Salt Lake City: The University of Utah Press, 1997), 267-308.

24 V-Phil-Th/Pölitz, AA 28:1118. Choć cytowany fragment pochodzi z notatek wydanych jako wykłady, biorąc pod uwagę jego zgodność z tezami zawartymi w pismach opublikowanych za życia filozofa, takimi jak esej Co oznacza: orientować się w myśleniu?, należy uznać, iż wyraża autentyczne poglądy Kanta. Por. fragment zaczynający się od słów: „Na pojęcie 
Zestawmy ten fragment $\mathrm{z}$ fragmentem pochodzącym z przedmowy do traktatu Die Göttlichkeit der Vernunft pewnego niemieckiego racjonalisty i wolnomyśliciela, Johanna Christiana Edelmanna:

Cóż ci pomoże, mój czytelniku, że od dawna już wiele słyszałeś o Bogu i uznajesz prawdę, że Bóg istnieje, skoro nie znasz go, lecz jedynie służysz myślnemu obrazowi (dem Gedanken-Bilde), który czy to sam sobie stworzyłeś, czy też pozwoliłeś, by inni go stworzyli dla ciebie? [...] Czyż nie wiesz, że to ty jesteś świątynią Boga i że znajdziesz tego Pana, niewidzialnego dla zewnętrznych zwierzęcych oczu, nie dalej niż w samym sobie? ${ }^{25}$

Pan ów, twierdzi Edelmann, cytując Ewangelię według św. Jana, „urządził sobie w nas swoje mieszkanie”, jego imię brzmi zaś - „,OГO $\Sigma$, to znaczy: rozum (die Vernunft)"26.

Jak widać z przytoczonych fragmentów, zarówno według Kanta, jak i Edelmanna rozum stanowi konieczny warunek objawienia się tego, co boskie przy czym pojawia się pytanie, czy objawienie to można rozumieć jako swego rodzaju doświadczenie wewnętrzne; czy ma ono, na przykład, naturę niedyskursywną - przeciwstawienie zaś objawienia wewnętrznego zewnętrzności dostępnej „zwierzęcym oczom” pozwala wnosić o bezpośrednim charakterze rozumowego ujęcia boskości. Jeśli dostęp do Boga jest bezpośredni i dany każdemu z nas, nie są potrzebni pośrednicy w relacji między (jakkolwiek pojętym) Bogiem a człowiekiem. Pisząc o „ślepych przewodnikach”, którzy rozpowszechniają „wymyślony obraz” Boga, Edelmann zapewne ma na myśli instytucje kościelne. Dla Kanta natomiast wewnętrzne objawienie stanowi podstawę wydawania sądów o wiarygodności objawienia zewnętrznego, które - jak dodaje - może wyrażać się „w słowach” lub „w czynach”.

Boga, a nawet przekonanie o jego istnieniu można natrafić jedynie w rozumie...” Kant, „Co oznacza...", 120.

25 Johann Christian Edelmann, Die Göttlichkeit der Vernunft in einer kurtzen Anweisung $z u$ weiterer Untersuchung der ältesten und vornehmsten Bedeutung des Wortes $\lambda$ oyoৎ (Berleburg 1742 [?]), 6 (tłum. - A.T.). W opinii historyków Edelmann, wychowany w religijności pietystycznej, był najbardziej radykalnym spinozjanistą w Niemczech przed Gottholdem Ephraimem Lessingiem. Zob. Leo Bäck, Spinozas erste Einwirkungen auf Deutschland (Berlin: Mayer \& Müller, 1895), 35.

${ }^{26}$ Edelmann, Die Göttlichkeit der Vernunft, 11-12. 
Wracając do zadanego wcześniej pytania, można więc powiedzieć, że nawet jeśli wiara miałaby stanowić konsekwencję uznania przez rozum własnych ograniczeń, tak pojmowaną wiarę uznaje Kant za wytwór rozumu i umieszcza ją, by tak rzec, w jego granicach. To racjonalistyczne stanowisko względem religii tłumaczy poniekąd sposób podejścia królewieckiego filozofa do objawienia zawartego „w słowach”, czyli do chrześcijańskiego Pisma św. Ten sposób podejścia będzie przedmiotem analiz w kolejnej części artykułu.

\section{Rozum jako narzędzie interpretacji objawienia}

Jak wspomniałam w poprzedniej części, rozumowe „objawienie wewnętrzne” ma dostarczać według Kanta kryterium oceny wiarygodności objawienia zawartego „w czynach” lub „w słowach”, co oznacza, że może ono także służyć jako narzędzie interpretacji tekstów uznawanych za święte na gruncie danej tradycji religijnej. Jak czytamy w Religii w obrębie samego rozumu, oparta na Piśmie św. „wiara kościelna” znajduje swoją właściwą interpretację w „czystej wierze religijnej”27, zwanej także przez Kanta „czystą wiarą rozumową"28. Interpretacja ta ma stanowić swego rodzaju łącznik między dwoma rodzajami wiary, pozwalając oddziaływać wierze rozumowej na ludzkie umysły za pośrednictwem wiary kościelnej. Kant pisze:

Żeby jednak pogodzić fundament moralnej wiary z taką wiarą empiryczną, którą los zesłał nam według swego uznania [...], konieczna jest jakaś interpretacja znajdującego się w naszych rękach objawienia, tj. wyjaśnienie go w takim uniwersalnym sensie, który byłby zgodny z powszechnymi praktycznymi regułami czystej rozumowej religii ${ }^{29}$.

Jeśli jednak prawdziwą religią jest czysta wiara rozumowa, czemu ma służyć oparta na Piśmie św. wiara kościelna? Odpowiedź Kanta korzysta z przesłanki antropologicznej. Ponieważ ludzie, przynajmniej w większości, kierują się zmysłami, aby przekazać wiernym treści „czystej rozumowej religii”,

\footnotetext{
${ }^{27}$ Kant, Religia w obrębie samego rozumu, 149.

28 Tamże, 141.

29 Tamże, 149-150.
} 
potrzebne są odpowiednie środki oddziałujące na ludzkie zmysły. Jednego z takich środków dostarcza Pismo św., przedstawiające historię konkretnych osób i zdarzeń w danym okresie ludzkich dziejów. Żadne jednak doświadczenie zmysłowe nie może nieść ze sobą poznania treści rozumowej wiary. Jak stwierdza Kant w Sporze fakultetów, nawet gdyby

Bóg rzeczywiście przemówił do człowieka, to ten nigdy nie mógłby wiedzieć, że to właśnie Bóg jest tym, kto do niego mówi. Jest całkowicie niemożliwe, by człowiek z pomocą swych zmysłów mógł dosięgnąć nieskończoności, odróżnić ją od tego, co zmysłowe i w ten sposób ją rozpoznaća ${ }^{30}$.

Dlatego też potrzebna jest interpretacja Pisma św. polegająca na przypisaniu składającym się na nie tekstom sensu etycznego. Oznacza to, że literalne odczytanie Biblii nie umożliwia dotarcia do takiego sensu, a ponieważ treścią prawdziwej religii, którą Kant utożsamia z „czystą wiarą rozumową”, jest moralność31, zdania wchodzące w skład tej księgi, jako takie, nie powinny być uznawane za prawdziwe. Jak jednak widać z podawanych przez Kanta przykładów, takie podejście do interpretacji Pisma św. prowadzi do rewizji jego tekstu i odrzucenia niektórych doktryn uznawanych za kanoniczne przez wiele chrześcijańskich denominacji. Mowa tu zwłaszcza o doktrynie Trójcy Św., zmartwychwstania, odkupienia czy powtórnego przyjścia Chrystusa ${ }^{32}$. Powstaje więc pytanie o uzasadnienie takiej właśnie - rewizjonistycznej - interpretacji.

Odpowiedź na to pytanie zdaje się napotykać pewne trudności. Myślę, że może tak być z co najmniej dwóch powodów. Po pierwsze, proponując taką wykładnię, Kant sytuuje się w nurcie już istniejących - w XVII i XVIII wieku sposobów interpretowania Pisma św. Z jednym z tych sposobów można spotkać się w rozprawie Die vornehmsten Wahrheiten der natürlichen Religion (1754) autorstwa Hermanna Samuela Reimarusa, którą - jak podaje Jonathan Israel - Kant podziwiał co najmniej przez dziesięć lat, odkąd się ukazała ${ }^{33}$.

30 Immanuel Kant, Spór fakultetów, przeł. Mirosław Żelazny (Toruń: Wydawnictwo Rolewski, 2003), 113.

31 Zob. tamże, 81-82.

32 Tamże, 84-86.

33 Jonathan Israel, „The Philosophical Context of Hermann Samuel Reimarus' Radical Bible Criticism", w: Between Philology and Radical Enlightenment. Hermann Samuel Reimarus (1694-1768), red. Martin Mulsow (Leiden-Boston: Brill, 2011), 189. 
Krytyczne interpretacje Biblii wychodziły także spod piór autorów, których umysłowość, podobnie jak Kantowska, kształtowała się pod wpływem tradycji pietystycznej. Należał do nich także wspomniany wcześniej Edelmann. Zdaniem Fredericka C. Beisera wielu z tych autorów, ulegając wpływom spinozjanizmu, „było rozczarowanymi dziećmi protestanckiej kontrreformacji” ${ }^{34}$. Paradygmatyczny przykład rewizjonistycznej interpretacji Pisma św. można także znaleźć w tak zwanym kręgu spinozjańskim ${ }^{35}$. Należeli do niego na przykład: Jarig Jelles, autor przedmowy do Opera posthuma (1677) Spinozy, w której starał się dowieść zgodności filozofii autora Etyki z podstawowymi naukami chrześcijaństwa, przytaczając wybrane fragmenty Biblii ${ }^{36}$; Lodewijk Meijer, który w rozprawie Philosophia Sanctae Scripturae interpres twierdził, że „tylko filozofia prawdziwa zdolna jest dostarczyć właściwego wyjaśnienia niezliczonych zagadek Pisma”37; czy Adriaan Koerbagh, który argumentował, że powinno się zachować z Biblii wyłącznie te doktryny, które „zgadzają się z rozumem”, oraz te, które on sam uznaje za Pismo, wszystko inne bowiem ,jest dla nas bezużyteczne i czcze, więc może być odrzucone bez skrupułów"38.

Po drugie, problem z uzasadnieniem interpretacji prowadzącej do odrzucenia jako nieistotnych dla wiary, gdyż niezgodnych z rozumem, wielu kanonicznych doktryn chrześcijaństwa może wiązać się ze specyfiką metody przyjętej przez Kanta. Metodę tę ilustruje znana z Przedmowy do drugiego wydania zawartej w Religii w obrębie samego rozumu metafora „okręgów koncentrycznych”, dotycząca relacji między objawieniem a „czystą wiarą rozumową". Zdaniem Kanta „filozof jako czysty teoretyk rozumu (opierający się na czystych pryncypiach a priori) musi pozostawać w obrębie tej ostatniej", a więc musi także „abstrahować od wszelkiego doświadczenia” ${ }^{39}$. Przypisywanie sensu

34 Frederick C. Beiser, The Fate of Reason. German Philosophy from Kant to Fichte (Cambridge, MA: Harvard University Press, 1987), 50. Kołakowski (w: Świadomość religijna i więź kościelna) w odniesieniu do protestanckich radykałów w Niderlandach używa określenia „druga reformacja”.

35 Określenie to pochodzi z pracy Koenraada Oege Meinsmy Spinoza en zijn kring (1896).

${ }^{36}$ Zob. Kołakowski, Świadomość religijna i więź kościelna, 163-169.

37 Koenraad Oege Meinsma, Spinoza und sein Kreis: Historisch-kritische Studien über holländische Freigeister, przeł. Lina Schneider (Berlin: Karl Schnabel Verlag, 1909), 345.

38 Tamże, 359.

39 Kant, Religia w obrębie samego rozumu, 34. 
etycznego tekstom objawienia wynikałoby tutaj z pewnej „próby” zbadania Pisma św. z perspektywy, w której dokonuje się abstrakcji od historycznych, to znaczy przygodnych, aspektów objawienia - próby odczytania świętego tekstu z perspektywy „samego rozumu”. Innymi słowy, ograniczony przyjętą metodą analizowania religii, Kant odrzuca te elementy wiary religijnej, które uznaje za mające inne niż rozum źródło - nie tylko zresztą empiryczne, ale także "ponadrozumowe” (supra rationem). Czy nie prowadzi to jednak do wniosku, że „w obrębie samego rozumu” nie da się uzasadnić religii objawionej, a zatem że ostatecznie - wbrew niektórym komentatorom ${ }^{40}$ - nie ma istotnej różnicy między religią rozważaną „W obrębie samego rozumu” a tą, która miałaby pochodzić tylko „z rozumu”?

Jeśli powyższe sugestie są trafne, uzasadniają przypisanie Kantowi pewnej wersji racjonalizmu religijnego, który - jak podkreśla Hunter - „obejmował szerokie spektrum zjawisk w kulturze, przybierających rozmaite formy”: od „ezoterycznej wiedzy” szerzonej w środowisku lóż masońskich po liberalną teologię protestanckąa ${ }^{41} \mathrm{Z}$ perspektywy tego ujęcia nie powinny więc dziwić próby wskazywania na podobieństwa między filozofią Kanta a spinozjanizmem czy też możliwe wpływy tego ostatniego na tę pierwszą, z jakimi możemy spotkać się zarówno wśród dziewiętnastowiecznych komentatorów ${ }^{42}$, jak i nieco bardziej współcześnie. Jedną z nich podjął Yirmiyahu Yovel w drugim tomie książki Spinoza and Other Heretics. Zdaniem Yovela Kant, tak samo jak Spinoza, uprawia filozofię immanencji, dopasowując pojęcie Boga do wymogów (i ograniczeń) skończonego ludzkiego rozumu. Co więcej, według izraelskiego filozofa „krytyka stanowi dla Kanta jednocześnie de-

40 Należał do nich na przykład dziewiętnastowieczny badacz Rudolf Reicke, według którego istotę Kantowskich rozważań o religii miałoby stanowić to, co „metodą analityczną” można wyabstrahować z objawienia, a co „sam (bloße) rozum może z siebie samego poznać”. Cyt. za: Josef Bohatec, Die Religionsphilosophie Kants in der Religion innerhalb der Grenzen der bloßen Vernunft (Hamburg: Hoffman und Campe, 1938), 36-37.

${ }^{41}$ Hunter, „Kant's Religion..., 9.

${ }^{42}$ Fragmenty traktujące o podobieństwach, jakie pod pewnymi względami zachodzą między poglądami Kanta i Spinozy, można znaleźć w: Jacob Freudenthal, „On the History of Spinozism”, The Jewish Quarterly Review 8/1 (1895): 17-70, oraz Max Grunwald, Spinoza in Deutschland: Gekrönte Preisschrift (Berlin: Calvary Verlag, 1897). Znamienne, że dokonując tego zestawienia, obaj autorzy interpretują spinozjanizm jako panteizm, a nie ateistyczny materializm. 
klarację niepodległości rozumu. Mimo swojej skończoności - ale także z jej powodu - ludzki rozum przejmuje rolę Boga jako prawodawcy zarówno natury, jak i moralności”"33. W jakim jednak sensie, jeśli w ogóle, można mówić o „przejęciu roli” Boga przez rozum - czyli deifikacji rozumu - na gruncie filozofii Kanta? Rozważę to zagadnienie w następnej części.

\section{Boskość rozumu?}

Mówiąc o deifikacji rozumu, można mieć na myśli przynajmniej dwie rzeczy: utożsamienie rozumu z Bogiem, czyli tezę, że wszystko, co ma charakter rozumny czy też racjonalny, ma tym samym Boską naturę; lub też przypisanie rozumowi pewnych cech czy własności, które zazwyczaj są przypisywane w określony sposób pojmowanemu Bogu. Odnosząc tezę o boskości rozumu do Kanta, należy oprzeć się raczej na tym drugim ujęciu, pamiętając jednak, że o faktycznie zachodzącej analogii nie może tutaj być mowy: argumenty zawarte w Dialektyce transcendentalnej przesądzają przecież o tym, że wszelkie próby orzekania czegokolwiek - łącznie z istnieniem - o Bogu pozostają nieuprawnione, o ile zakładamy, że orzeczeniom tym ma przysługiwać określona wartość poznawcza. Będę więc twierdzić, że Kant - zwłaszcza w swoim późnym, niedokończonym dziele wydanym jako Opus postumum - przypisuje rozumowi pewne cechy, które na gruncie metafizyki teistycznej bywają przypisywane Bogu, lecz nie odnosi się przy tym do bytu boskiego.

Zanim jednak przedstawię uzasadnienie tezy, zgodnie z którą według Kanta ludzki rozum miałby „przejąć rolę Boga”, zarysuję pokrótce przemiany, jakim podlegała Kantowska koncepcja Boga od pism przedkrytycznych po Opus postumum. Tak więc w eseju z 1755 roku, Nowe wyjaśnienie pierwszych zasad poznania metafizycznego, pojawia się argument za istnieniem Boga z pojęcia możliwości, który Kant rozwinie w Jedynej możliwej podstawie dowodu na istnienie Boga (1763). Argument ten można streścić następująco ${ }^{44}$ : jeśli cokol-

43 Yirmiyahu Yovel, Spinoza and Other Heretics. The Adventures of Immanence (Princeton, NJ: Princeton University Press, 1989), 7.

44 Bardziej szczegółowe omówienie tego „dowodu” na istnienie Boga można znaleźć w: Anna Tomaszewska, „Bóg Spinozy w pismach przedkrytycznych Kanta”, w: Filozofia 
wiek jest możliwe, musi istnieć byt konieczny, a więc taki, którego istnienie warunkuje wszelką możliwość. Byt koniecznie istniejący jest Bogiem, gdyż taki byt nie ma żadnych ograniczeń, jest nieskończony. Co ciekawe, mimo że Kant zdaje się odżegnywać od Spinozjańskiej koncepcji Boga w przedkrytycznych esejach, podkreślając, iż Bóg jest bytem, któremu przede wszystkim przysługuje intelekt i wola, niektórzy autorzy dostrzegli panteistyczne konsekwencje argumentu z możliwości ${ }^{45}$. Miałyby one wynikać z przyjętego przez Kanta rozróżnienia między tym, co możliwe realnie, a tym, co możliwe logicznie, oraz uznania, że to, co możliwe realnie, musi mieć swoją podstawę w czymś aktualnie istniejącym, stanowiącym jak gdyby egzemplifikację realnych możliwości ${ }^{46}$.

Jak wiadomo, w okresie krytycznym Kant kwestionuje zdolność rozumu teoretycznego do wykazania prawdziwości tezy teistycznej, odrzucając argumenty: ontologiczny, kosmologiczny i fizykoteologiczny. Argument z możliwości jednak zostaje w krytyce "dowodów” teistycznych pominięty, a przedkrytyczna koncepcja Boga jako podstawy wszystkiego, co realne (ens realissimum), zostaje przekształcona $\mathrm{w}$ koncepcję ideału transcendentalnego jako „najwyższego i całkowitego materialnego warunku [...] możliwości [wszechstronnego określenia - przyp. A.T.], do którego, co do swej treści, musi być sprowadzone wszelkie myślenie przedmiotów w ogóle" ${ }^{\text {47 }}$. Bóg staje się tutaj odpowiednikiem idei przedmiotu zawierającego w sobie wszystkie możliwe do pomyślenia treści.

Negując zdolność rozumu teoretycznego do udowodnienia istnienia Boga, Kant zachowuje jednak możliwość wykazania prawdziwości tezy teistycznej jako postulatu rozumu praktycznego. Praktyczny argument za istnieniem Boga, odwołujący się do pojęcia najwyższego dobra, pojawia się w różnych miejscach, między innymi w należącym do pierwszej Krytyki rozdziale O ideale najwyższego dobra, w eseju Co oznacza: orientować się w myśleniu?,

Oświecenia. Radykalizm - religia - kosmopolityzm, red. Justyna Miklaszewska, Anna Tomaszewska (Kraków: Wydawnictwo Uniwersytetu Jagiellońskiego, 2015), 305-329.

45 Miał się do nich zaliczać Friedrich Heinrich Jacobi, zdaniem którego Kant „w sposób niezamierzony dowiódł konieczności panteizmu”. Zob. Beiser, The Fate of Reason, 55.

${ }^{46} \mathrm{~W}$ sprawie dokładniejszego omówienia tych konsekwencji oraz dotyczącej ich współczesnej debaty zob. Tomaszewska, „Bóg Spinozy w pismach przedkrytycznych Kanta”.

${ }^{47}$ Kant, Krytyka czystego rozumu, 465 (KrV, A 576/B 604). 
a także w II rozdziale II księgi Krytyki praktycznego rozumu. Pomijając różnice zachodzące między wersjami tego argumentu ${ }^{48}$, można powiedzieć, że sprowadza się on w istocie do stwierdzenia, że istnienie Boga jako „postulat czystego praktycznego rozumu” stanowi warunek obiektywnej realności czy też możliwości realizacji ideału najwyższego dobra - to znaczy wspomnianego w drugiej części tego artykułu proporcjonalnego powiązania moralności i szczęścia.

W Religii w obrębie samego rozumu Kant rozwija koncepcję Boga jako suwerena wspólnoty etycznej, argumentując w następujący sposób. Rodzaj ludzki ma względem samego siebie moralny obowiązek porzucenia „etycznego stanu natury" i realizowania ideału najwyższego dobra. Zadanie to nie jest możliwe do wykonania dla poszczególnych jednostek, gdyż żyjąc w społeczeństwie, ulegają one skłonności do niszczenia nawzajem „swoich moralnych predyspozycji”" ${ }^{49}$. Innymi słowy, według Kanta, żyjąc wśród ludzi, nieustannie deprawujemy ich i pozwalamy deprawować samych siebie, podlegamy bowiem pewnym mechanizmom życia społecznego, takim jak rywalizacja czy porównywanie się z innymi, generującym moralne przywary. Potrzebna jest więc wspólnota, dzięki której nasze dążenie do realizacji ideału moralnego będzie wzmacniane, a nie udaremniane. Pod jakim warunkiem jest ona możliwa, Kant wyjaśnia w następujący sposób:

Każdy gatunek rozumnych istot jest [...] w samej idei rozumu obiektywnie powołany do [realizowania] wspólnego celu, mianowicie do pielęgnowania najwyższego dobra jako dobra wspólnego. Jednak najwyższe moralne dobro jest nie do zrealizowania poprzez dążenie jednostki do swej moralnej doskonałości, lecz wymaga to zjednoczenia jednostek - ze względu na ten cel - w całość, w system ludzi o dobrym usposobieniu, w którym i przez jedność którego może się to dopiero urzeczywistnić. [...] Tym samym jest to obowiązek, który co do rodzaju i pryncypium różni się od wszystkich. - Z góry możemy przypuszczać, że ten obowiązek będzie wymagał założenia innej idei, mianowicie wyższej moralnej istoty. Dopiero za jej sprawą nastąpi powszechne zjednoczenie sił

48 Analizę tych różnic przeprowadza Eckart Förster w 5 rozdz. książki Kant's Final Synthesis. An Essay on the Opus postumum (Cambridge, MA: Harvard University Press, 2000).

49 Kant, Religia w obrębie samego rozumu, 134. 
poszczególnych jednostek (które same z siebie są niewystarczające) do wspólnych działań ${ }^{50}$.

Warunkiem wspólnoty etycznej jest więc istnienie Boga jako zwierzchnika i prawodawcy tej wspólnoty, który zarazem jest „znawcą serc" ${ }^{51}$. Wydaje się, że Bóg pełni tutaj rolę czynnika harmonizującego dążenia do dobra poszczególnych podmiotów moralnych, które przecież mogą znajdować się na różnych etapach realizacji moralnego ideału. Można zauważyć, że argument znajdujący się w Religii przypomina dowód twierdzenia 13 Nowego wyjaśnienia, który odwołuje się do pojęcia relacji ${ }^{52}$ : podobnie jak powiązanie substancji relacjami zewnętrznymi (przyczynowość, styczność w czasie i przestrzeni) zakłada istnienie czynnika odpowiadającego za to powiązanie (tworzenie relacji z innymi obiektami nie należy bowiem do natury poszczególnych substancji założenie to Kant przejmuje z monadologii Gottfrieda Wilhelma Leibniza), tak samo połączenie jednostkowych wysiłków zmierzających do urzeczywistnienia moralności w świecie wymaga, aby istniał czynnik jednoczący owe wysiłki nakierowane na wspólny cel, czy też nadający im pewien porządek (odpowiednia proporcja szczęśliwości do moralnych zasług). Zgodnie z tą analogią porządek moralny, tak jak porządek empiryczny, zakładałby istnienie pewnego czynnika, któremu można by przypisać jego autorstwo.

Oczywiście, biorąc pod uwagę rezultaty Kantowskiej krytyki metafizyki dogmatycznej, można zadać pytanie o status, jaki miałby przysługiwać owej transcendentnej rzeczywistości - porządkowi moralnemu na czele $\mathrm{z}$ boskim zwierzchnikiem. Co ważniejsze, jaką rolę rzeczywistość ta miałaby odgrywać z praktycznego punktu widzenia, jeżeli o moralnej wartości postępowania decyduje tylko to, czy zostało ono podjęte ze względu na prawo moralne? ${ }^{53}$ To oznacza, że wyobrażenie świata, w którym realizowany jest ideał dobra

\footnotetext{
50 Tamże, 135.

51 Tamże, 137.

52 Zob. Tomaszewska, „Bóg Spinozy w pismach przedkrytycznych Kanta”, 323 (przypis).

53 Stosownie do tego w rozdz. I Uzasadnienia metafizyki moralności Kant odróżnia czyny podjęte $z$ obowiązku, a więc motywowane szacunkiem do prawa moralnego, od czynów zgodnych $z$ obowiązkiem, gdy pobudkę woli mogą stanowić rozmaite skłonności. „Przeto nic innego - czytamy - ale tylko samo przedstawienie prawa, które co prawda występuje jedynie w istocie rozumnej, wtedy, kiedy ono, a nie oczekiwany skutek, jest pobudką woli, może stanowić to szczególne dobro, które nazywamy moralnym i które znajduje się już w samej osobie
} 
najwyższego, nie jest istotne $\mathrm{z}$ perspektywy moralności. Krótko mówiąc, $\mathrm{z}$ moralnego punktu widzenia wiara w Boga wydaje się nie mieć znaczenia.

Tak więc z jednej strony Kant twierdzi, że możliwość urzeczywistnienia ideału moralnego wymaga założenia o istnieniu Boga - suwerena wspólnoty etycznej - $z$ drugiej zaś nie uznaje poglądu, zgodnie z którym przyjęcie przesłanki teistycznej miałoby stanowić warunek moralności postępowania. Nie ma tu jednak sprzeczności, jeśli uznać realizację dobra najwyższego, a tym samym przyjęcie tezy o istnieniu Boga, za (pożądaną) konsekwencję moralności, a nie jej warunek. Jak czytamy w Przedmowie do wydania pierwszego zawartej w Religii w obrębie samego rozumu, „etyka prowadzi nieodzownie [oryg. unumgänglich - przyp. A.T.] do religii” ${ }^{4}$, przy czym „nieodzowność” nie oznacza jeszcze koniecznego wynikania. (Parafrazując: jeśli cokolwiek miałoby być konsekwencją etyki, to będzie nią religia).

W Opus postumum krytyczna doktryna postulatów czystego praktycznego rozumu wydaje się ulegać dezintegracji55. Wprawdzie Kant przyznaje, że „moralno-praktyczny rozum, o ile zawiera prawidła obowiązku (reguły postępowania zgodnie $\mathrm{z}$ imperatywem kategorycznym), prowadzi do pojecia Boga" ${ }^{56}$, ale kwestia istnienia Boga pozostaje otwarta: niektóre fragmenty sugerują, że istnienie to wynika $\mathrm{z}$ samego pojęcia obowiązku, inne pozwalają podać $\mathrm{w}$ wątpliwość, czy wyprowadzonemu w ten sposób pojęciu Boga odpowiada jakikolwiek rzeczywisty przedmiot. Zestawmy ze sobą następujące dwa fragmenty:

(1) Istnieje w rozumie praktycznym pojęcie obowiązku, to jest przymusu czy konieczności zgodnie z zasadą praw wolności - to jest, według prawa, które podmiot sam sobie przepisuje (dictamen rationis practicae), i to za pomocą imperatywu kategorycznego [...]. Nakaz, któremu każdy winien absolutne posłuszeństwo, powinien być uznawany za taki, który pochodzi od istoty panującej nad wszystkimi i rozkazującej wszystkim. Taką istotę jednakże nazywa się Bogiem. A zatem jest Bóg ${ }^{57}$.

według niego postępującej...”. Immanuel Kant, Uzasadnienie metafizyki moralności, przeł. Mścisław Wartenberg (Kęty: Wydawnictwo Marek Derewiecki, 2009), 18.

${ }^{54}$ Kant, Religia w obrębie samego rozumu, 28.

55 Por. Cortina, „Die Auflösung des religiösen Gottesbegriffs im Opus postumum Kants”.

56 OP, AA 22:116 (kursywa - A.T.).

57 OP, AA 22:126-7. 
(2) Nadal jednak, jak się zdaje, pozostaje pytanie, czy tej idei, wytworowi naszego własnego rozumu, przysługuje realność, czy też jest ona jedynie bytem myślnym (ens rationis) i nie pozostaje nam nic oprócz relacji moralnej do tego przedmiotu [scil. Boga - przyp. A.T.] - która jest co najwyżej problematyczna, pozostawiając jedynie formułę mówiącą o znajomości wszystkich ludzkich obowiązków jako (tanquam) boskich nakazów... ${ }^{58}$

Argument zawarty w pierwszym z zacytowanych fragmentów przypomina nieco rozumowanie Kartezjusza z Medytacji II, w której istnienie podmiotu myślącego zostaje wyprowadzone bez żadnej dodatkowej przesłanki, bezpośrednio z aktu myślenia. Być może więc fragment ten dałoby się odczytać jako ustalający pojęciową zależność między prawem moralnym a istnieniem Boga, ale taki wniosek popada w sprzeczność z jedną z kluczowych tez Kanta z okresu krytycznego - mianowicie, że wszelkie sądy egzystencjalne mają charakter syntetyczny, a wobec tego nie można ich wyprowadzić na drodze analizy pojęciowej.

W drugim fragmencie nie ma już mowy o istnieniu Boga. Bóg uzyskuje tutaj raczej status idei moralno-praktycznego rozumu - „samej tylko idei czystego rozumu, który bada swoje własne zasady"59 - a istnienie przedmiotu tej idei nie tylko nie może być konkluzywnie stwierdzone, ale nawet nie stanowi koniecznego warunku wiary religijnej. Co więcej, „aby mieć religię, nie jest potrzebne pojęcie Boga, ani tym bardziej postulat «Istnieje Bóg»" "60, choć „rozum nieuchronnie stwarza sobie obiekty. Stąd też wszystko, co myśli, ma Boga" ${ }^{1}$. Tak rozumiany, jako idea-obiekt rozumu, Bóg nie jest transcendentną substancją, lecz istnieje „w nas”, w naszym własnym rozumie. Kant pisze:

Cechą właściwą istocie moralnej, która może wydawać kategoryczne nakazy naturze człowieka, jest jej boskość. Jej prawa muszą być przestrzegane jako boskie nakazy. Czy religia jest możliwa bez założenia o istnieniu Boga. Est deus in nobis ${ }^{62}$.

\footnotetext{
58 OP, AA 22:117.

59 OP, AA 22:53. Zob. też OP, AA 21:21; 21:27; 21:52.

${ }^{60}$ OP, AA 21:81.

61 OP, AA 21:83.

62 OP, AA 22:130. Zob. także OP, AA 22:55; 21:17; 21:25.
} 
Jedna z podstawowych różnic między Kantowską koncepcją Boga z okresu krytycznego a tą koncepcją, którą znajdujemy w Opus postumum, wydaje się zatem polegać na rezygnacji z przeświadczenia, że rozum praktyczny może wykazać konieczność istnienia Boga transcendentnego względem tego rozumu. Tradycja chrześcijańska zna rzecz jasna figurę „Boga w nas” czy też "transcendencji w immanencji” - przykładem może być chociażby koncepcja sumienia jako „głosu Boga” objawiającego wieczne prawo wpisane w racjonalną naturę człowieka, którą rozwijał John Henry Newman ${ }^{63}$. Można jednak wątpić, czy fragmenty Opus postumum mówiące o „Bogu w nas” nawiązują do chrześcijańskiej koncepcji transcendentnego Boga, jeśli wziąć pod uwagę inne fragmenty, w których Kant dość wyraźnie utożsamia Boga z rozumem praktycznym. Te ostatnie znajdziemy zarówno w zbiorze VII, jak i późniejszym zbiorze I, w którym Kant zarysowuje nową teorię filozofii transcendentalnej. Oto przykłady:

(1) Pojęcie Boga jest ideą istoty moralnej, która jako taka osądza [oraz] wydaje uniwersalne nakazy. Ta ostatnia [scil. istota - przyp. A.T.] nie jest przedmiotem hipotetycznym, ale samym czystym spersonifikowanym rozumem praktycznym.... ${ }^{64}$

(2) [Z] praktycznego punktu widzenia jest rzeczą obojętną, czy boskość nakazu ma swoje ugruntowanie w ludzkim rozumie, czy też w takiej osobie [scil. w Bogu - przyp. A.T.], gdyż różnica dotyczy sposobu wyrażania się, nie zaś doktryny rozszerzającej nasze poznanie ${ }^{65}$.

W jaki sposób można uzasadnić zwrot Kanta w kierunku koncepcji Boga immanentnego, rozumianego jako personifikacja praktycznego rozumu, czy też samego prawa moralnego, jak czytamy w Vorlesungen über die philosophische Religionslehre? ${ }^{26}$ Istnieją co najmniej dwie racje, które przemawiają za tym zwrotem. Po pierwsze, w nowej koncepcji filozofii transcendentalnej, której zarys znajdziemy w I zbiorze notatek wchodzących w skład Opus

${ }_{63}$ Zob. John Henry Newman, List do księcia Norfolk. O sumieniu, przeł. Anna Muranty (Bydgoszcz: Wydawnictwo Homini, 2002).

${ }^{64}$ OP, AA 22:118.

65 OP, AA 21:28.

66 V-Phil-Th/Pölitz, AA 28:1091. 
postumum, problem relacji między sferą moralną, stanowiącą dziedzinę wolności, a podlegającą deterministycznym prawom dziedziną przyrody uzyskuje nowe rozwiązanie. Łącznikiem między tymi dwiema dziedzinami jest teraz człowiek - „racjonalny podmiot” i istota wolna ${ }^{67}$, przy czym obie sfery konstytuują się w odniesieniu do idei (entia rationis), odpowiednio, Boga i świata ${ }^{68}$. Tym samym argument odwołujący się do pojęcia najwyższego dobra traci na znaczeniu: zamiast postulatu istnienia Boga mamy teraz system idei czystego rozumu, w którym idea Boga odgrywa znaczącą rolę. Jak pisze Eckart Förster, komentując konstytutywną rolę idei Boga w nowym systemie filozofii transcendentalnej Kanta:

W zdaniu „Bóg istnieje” [...] nie jest właściwie postulowane istnienie istoty niezależnej od ludzkiego myślenia i działania [...]. W zdaniu tym raczej postulowane jest coś, co nadaje "moc poruszającą" należącym do praktycznego rozumu ideom prawa, umożliwiając ich jedność [...]. W tym celu muszą one być postrzegane jako pochodzące od moralnego suwerena rodzaju ludzkiego, chociaż to sam rozum praktyczny stanowi źródło nakazu moralnego. Stąd też zdanie „Bóg istnieje” oznacza, że istnieje on w rozumie praktycznym ${ }^{69}$.

Po drugie, Kantowski zwrot ku immanencji można uzasadnić jako konsekwencję doktryny autonomii rozumu praktycznego jako moralnego prawodawcy. Mówiąc o „obowiązkach jako boskich nakazach” w wielu fragmentach Opus postumum ${ }^{70}$, Kant nawiązuje do definicji religii, która często powraca w jego pismach krytycznych. Dla przypomnienia: zgodnie z tą definicją religia stanowi „sumę wszystkich obowiązków ujmowanych jako (instar) boskie przykazania"71. Jeśli obowiązki te będziemy rozumieć jako obowiązki moralne, to sens definicji Kantowskiej okaże się następujący: religia jest moralnością traktowaną w taki sposób, jak gdyby była nakazana przez Boga. Ale

67 OP, AA 21:21-3.

${ }^{68} \mathrm{O}$ konstytutywnej roli idei transcendentalnych i odwróceniu znanych z Krytyki czystego rozumu relacji między intelektem a rozumem w Opus postumum pisze Förster w 6 rozdz. Kant's Final Synthesis.

69 Tamże, 142.

70 Zob. OP, AA 22:119-120; 21:12; 21:15; 21:17.

71 Immanuel Kant, Metafizyczne podstawy nauki prawa, przeł. Włodzimierz Galewicz (Kęty: Wydawnictwo Marek Derewiecki, 2006), 167 (MS TL, AA 6:487). 
źródłem moralności według Kanta jest rozum praktyczny, czyli wola, której autonomia polega na działaniu zgodnie z prawem, jakie sama sobie nadaje ${ }^{72}$. Ujęcie obowiązków moralnych jako boskich nakazów nie może być równoznaczne $\mathrm{z}$ odrzuceniem autonomii, lecz raczej z przypisaniem rozumowi praktycznemu pewnych kompetencji, które dotychczas, na gruncie teistycznej metafizyki, a w szczególności wywodzących się z filozofii kartezjańskiej koncepcji nowożytnych, przypisywano Bogu. Określając obowiązki mianem boskich nakazów, a jednocześnie zachowując ideę autonomii w zakresie nadawania prawa moralnego, Kant musi dokonać utożsamienia rozumu praktycznego $w$ jego funkcji prawodawczej z Bogiem, o ile nie ma głosić poglądu wewnętrznie sprzecznego. Tym samym wspomniana w tytule tej części „boskość rozumu” nie oznaczałaby - by posłużyć się słowami Christophera Insole’a - jego „przebóstwienia” osiąganego dzięki „boskiemu działaniu oraz uczestnictwu w bóstwie"73, ale samowystarczalność, która charakteryzuje rozum jako moralnego prawodawcę.

\section{Uwagi końcowe}

W niniejszym artykule starałam się wskazać na pewne wątki pozwalające dostrzec istotne podobieństwa między filozofią religii Kanta a zbiorem idei określanych w literaturze przedmiotu mianem racjonalizmu religijnego. Wątki te to krytyka chrześcijańskiego objawienia, polegająca na „dopasowaniu” jego treści do „wymogów «naturalnego» rozumu”, oraz koncepcja Boga jako idei immanentnej ludzkiemu rozumowi, a nawet jako tożsamego z tym rozumem (przynajmniej pod pewnymi względami).

Mimo tych podobieństw można powiedzieć, że choć Kant, sprowadzając istotę religii do podążania za nakazami rozumu praktycznego, podobnie jak przedstawiciele „protestanckiej kontrreformacji” osłabia znaczenie pośredników w relacji między (jakkolwiek pojętym) Bogiem a człowiekiem, takich

${ }^{72}$ Kant, Uzasadnienie metafizyki moralności, 49-50 (GMS, AA 4:433), 57 (GMS, AA 4:440).

${ }^{73}$ Insole, The Intolerable God, 130. 
jak teksty uważane na gruncie danej tradycji za objawione czy instytucje religijne, to jednak przyznaje im dość ważną rolę narzędzi propagowania „czystej wiary rozumowej”. Tym samym zostają one wprzęgnięte w proces ewolucyjnego „przejścia do [...] nowego porządku rzeczy” i ustanowienia „(boskiego) etycznego państwa na ziemi”"74. To by oznaczało, że w odróżnieniu od zainspirowanych Spinozą radykalnych reformatorów czy przedstawicieli radykalnego Oświecenia Kant nie odrzuca religii objawionej - zachowuje ją jednak tylko po to, by zredefiniować jej rolę i znaczenie.

\section{Bibliografia}

Bäck Leo. 1895. Spinozas erste Einwirkungen auf Deutschland. Berlin: Mayer \& Müller.

Beiser Frederick C. 1987. The Fate of Reason. German Philosophy from Kant to Fichte. Cambridge, MA: Harvard University Press.

Bohatec Josef. 1938. Die Religionsphilosophie Kants in der Religion innerhalb der Grenzen der bloßen Vernunft. Hamburg: Hoffman und Campe.

Cortina Adela. 1984. „Die Auflösung des religiösen Gottesbegriffs im Opus postumum Kants". Kant-Studien 75/3: 280-293.

Dilthey Wilhelm. 1990. „Der Streit Kants mit der Zensur über das Recht freier Religionsforschung". W: Die Jugendgeschichte Hegels und andere Abhandlungen zur Geschichte des deutschen Idealismus, 285-309. Göttingen: Vandenhoeck und Ruprecht.

Edelmann Johann Christian. 1742 [?]. Die Göttlichkeit der Vernunft in einer kurtzen Anweisung zu weiterer Untersuchung der ältesten und vornehmsten Bedeutung des Wortes גoyos. Berleburg.

Fischer Norbert (hrsg.). 2005. Kant und der Katholizismus. Stationen einer wechselhaften Geschichte. Freiburg im Breisgau: Herder.

Förster Eckart. 2000. Kant's Final Synthesis. An Essay on the Opus postumum. Cambridge, MA: Harvard University Press.

Freudenthal Jacob. 1895. „On the History of Spinozism”. The Jewish Quarterly Review 8/1: 17-70.

Grunwald Max. 1897. Spinoza in Deutschland: Gekrönte Preisschrift. Berlin: Calvary Verlag.

${ }^{74}$ Kant, Religia w obrębie samego rozumu, 164. 
Hunter Ian. 2005. „Kant's Religion and Prussian Religious Policy”. Modern Intellectual History 2/1: 1-27.

Insole Christopher. 2016. The Intolerable God: Kant's Theological Journey. Grand Rapids MI: Eerdmans.

Israel Jonathan. 2001. Radical Enlightenment. Philosophy and the Making of Modernity 1650-1750. Oxford: Oxford University Press.

Israel Jonathan. 2011. „The Philosophical Context of Hermann Samuel Reimarus' Radical Bible Criticism". W: Between Philology and Radical Enlightenment. Hermann Samuel Reimarus (1694-1768), red. Martin Mulsow, 183-200. Leiden-Boston: Brill.

Kant Immanuel. 1900ff. Gesammelte Schriften. Hrsg.: Bd. 1-22 Preussische Akademie der Wissenschaften, Bd. 23 Deutsche Akademie der Wissenschaften zu Berlin, ab Bd. 2 Akademie der Wissenschaften zu Göttingen. Berlin.

Kant Immanuel. 2001. Krytyka czystego rozumu, przeł. Roman Ingarden. Kęty: Wydawnictwo Antyk.

Kant Immanuel. 2003. Spór fakultetów, przeł. Mirosław Żelazny. Toruń: Wydawnictwo Rolewski.

Kant Immanuel. 2006. Rozprawa filozoficzna o religii $i$ moralności/Philosophische Abhandlung über Religion und Moral, przeł. Krzysztof Celestyn Mrongowiusz. Toruń: Wydawnictwo Uniwersytetu Mikołaja Kopernika.

Kant Immanuel. 2006. Metafizyczne podstawy nauki prawa, przeł. Włodzimierz Galewicz. Kęty: Wydawnictwo Marek Derewiecki.

Kant Immanuel. 2007. Religia w obrębie samego rozumu, przeł. Aleksander Bobko. Kraków: Wydawnictwo Homini.

Kant Immanuel. 2009. „Co oznacza: orientować się w myśleniu?”. W: O odkryciu, po którym wszelka nowa krytyka czystego rozumu jest zbędna ze względu na istnienie wcześniejszej i inne rozprawy filozoficzne, przeł. Translatorium Filozofii Niemieckiej Instytutu Filozofii UMK, 109-126. Toruń: Wydawnictwo Naukowe Uniwersytetu Mikołaja Kopernika.

Kant Immanuel. 2009. Uzasadnienie metafizyki moralności, przeł. Mścisław Wartenberg. Kęty: Wydawnictwo Marek Derewiecki.

Kołakowski Leszek. 2009. Świadomość religijna i więź kościelna. Warszawa: WN PWN.

Kupś Tomasz. 2016. Opus postumum Immanuela Kanta. Toruń: Wydawnictwo Naukowe Uniwersytetu Mikołaja Kopernika.

Meinsma Koenraad Oege. 1909. Spinoza und sein Kreis: Historisch-kritische Studien über holländische Freigeister. Berlin: Karl Schnabel Verlag.

Newman John Henry. 2002. List do księcia Norfolk. O sumieniu, przeł. Anna Muranty. Bydgoszcz: Wydawnictwo Homini. 
O’Neill Onora. 1997. „Kant on Reason and Religion”. W: The Tanner Lectures on Human Values, red. Grethe B. Peterson, 267-308. Salt Lake City: The University of Utah Press.

Palmquist Stephen. 1992. „Does Kant Reduce Religion to Morality?”. Kant-Studien 83/2: 129-148.

Palmquist Stephen. 2015. Comprehensive Commentary on Kant's Religion within the Bounds of Bare Reason. Oxford and Chichester: Wiley Blackwell.

Paulsen Friedrich. 1899. Kant, der Philosoph des Protestantismus. Berlin: Reuther und Reichard.

Tomaszewska Anna. 2015. „Bóg Spinozy w pismach przedkrytycznych Kanta”. W: Filozofia Oświecenia. Radykalizm - religia - kosmopolityzm, red. Justyna Miklaszewska, Anna Tomaszewska, 305-329. Kraków: Wydawnictwo Uniwersytetu Jagiellońskiego.

Wood Allen. 1991. „Kant's Deism”. W: Kant's Philosophy of Religion Reconsidered, red. Philip J. Rossi, Michael J. Wreen, 1-21. Bloomington: Indiana University Press.

Yovel Yirmiyahu. 1989. Spinoza and Other Heretics. The Adventures of Immanence. Princeton, NJ: Princeton University Press.

\section{Abstract \\ Kant's Philosophy of Religion in the Context of Early Modern Religious Rationalism}

The article analyses certain aspects of Kant's conception of religion which testify to its affinity with what has been described as religious rationalism. These aspects include a critical reading of the Scriptures, proposed primarily in the Religion within the Boundaries of Mere Reason and The Conflict of the Faculties, as well as an attempt to identify God with practical reason, which can be found in the notes written for the unfinished work of the philosopher, published as the Opus postumum. I suggest that by reading Kant in light of the ideas of the early modern religious rationalists, especially those inspired by the thought of Baruch Spinoza, one can better explain the radicalization of Kant's late views on religion, recognized by some contemporary scholars.

Keywords: Immanuel Kant, religion, religious rationalism, revelation, practical reason. 


\section{Streszczenie}

\section{Filozofia religii Kanta w kontekście nowożytnego racjonalizmu religijnego}

Celem artykułu jest wskazanie pewnych aspektów koncepcji religii Kanta, świadczących o jej powinowactwie $\mathrm{z}$ nurtem określanym w literaturze przedmiotu mianem racjonalizmu religijnego. Wątki te to między innymi krytyczna interpretacja Pisma św., zaproponowana przez Kanta przede wszystkim w Religii w obrębie samego rozumu, a także w Sporze fakultetów, jak również próba utożsamienia Boga i rozumu praktycznego, którą można napotkać, czytając fragmentaryczne notatki niedokończonego dzieła filozofa, wydane jako Opus postumum. Zgodnie z przedstawioną propozycją interpretacja Kantowskiej filozofii religii w odniesieniu do idei religijnych racjonalistów, zwłaszcza tych zainspirowanych myślą Barucha Spinozy, pozwala lepiej zrozumieć dostrzeganą przez współczesnych badaczy radykalizację myśli Kanta, zwłaszcza w jej późnej fazie.

Słowa kluczowe: Immanuel Kant, religia, racjonalizm religijny, objawienie, rozum praktyczny. 